\title{
Sexual Abuses: Forensic Medicine and Forensic Genetics Aspects
}

\author{
Ciro Giobbe* \\ Forensic Biologist, Italy
}

Submission: April 24, 2017; Published: July 26, 2017

*Corresponding author: Ciro Giobbe, Forensic DNA Analyst, Freelancer, technical consultant at Torre Annunziata Courthouse. Via Nazionale, 92, 80059, Torre del Greco, Neaples, Italy, Tel: +39 3394385223; Email: agesci85@hotmail.it

\begin{abstract}
Today, sexual assaults occur worldwide: in all cultures and social classes. The victim of sexual violence where it needs to go? To those who need to contact the victim? What should she do? But most importantly, what she should not do? As far as they are concerned, law Enforcements, paramedic and medical personnel and forensic scientists work constantly and professionally to prevent them, help victims and discover aggressors. In consideration of this kind of crimes, it is important to analyze: victim's health conditions and needs; The familiar (or extrafamiliar) context in which an assault has occurred and the relationship between the victim and the aggressor; Legal aspects. Medical and genetic examinations on the victim of sexual violence take priority, like the psychological support, and I must not be neglected.
\end{abstract}

Keywords: Sexual Abuse; Rape; DNA analysis; Forensic genetics; Medical examination

\section{Introduction}

The phenomenon of violence against women is a very broad and spread one. 6,788,000 women have suffered some form of physical or sexual abuse in their lives, 31, 5\% between 16 and 70 years old: $20,2 \%$ suffered physical violence, $21 \%$ sexual abuse, $5,4 \%$ more serious forms of sexual abuse like rape or attempted rape. 652,000 are the number of women who suffered rapes and 746,000 are the victims of attempted rapes. This is just a partial picture of the many sexual abuse scenarios occurring in every culture, social class and wherever in the world. It is in such scenarios that law enforcement agency, medical and nursing personnel and forensic geneticists are involved and constantly work in order to prevent this kind of violence, with the aim to help victims and identify people in charge.

Such crimes show many aspects relevant to the contexts in which they arose (familiar or extra-familiar), to the specific relation between the victim and the aggressor, to the effects on the psycho-physic health of the victim and to the long and unpredictable judiciary red tape linked to such events, inevitably interfering with all other aspects.

Consequently, each external intervention has to be necessarily integrated to all the others, which have to be considered, taking into account the victim's exigencies, conditions and needs.

This idea is expressed by a univocal definition in the OMS guidelines published in "Guidelines for medico-legal care for victims of sexual violence" [1], claiming that when taking care of sexual violence victims, the absolute priority has always to be given to the patient's health and well-being. Therefore, the disposition of medico-legal services assumes a secondary importance in relation to general health care services (treatment of injuries, evaluation and handling of mental health, of the state of pregnancy and of sexual transmitted diseases). The application of a forensic exam without affording the patients' basic health care exigencies results negligent.

Therefore, after having met the victim's primary necessities, always considered the first objective in each intervention, one can and has to start dealing with the judiciary issues, which include their investigative and probative aspects. If they are correctly and promptly set, according to consolidated procedures and by means of the acquisition of definite clinical elements, they will be suitable to guide the physician in collecting information and useful materials for the detection and identification of the aggressor. From this perspective, in the context of a sexual abuse, the victim is both the witness of the event and the central element of the crime scene, which provides useful elements the physician, can resort to, in order to reach the legal resolution of the issue [2].

Nevertheless, despite the difficulties, limitations and cautions due to episodes of sexual abuse, medico-forensic surveys have, undoubtedly, significant repercussions on the 
investigation outcomes and on successive judgments. They are to be collected promptly and without any hesitation, and above all, a correct methodology has to be applied. Thus, once the primary sanitary exigencies conducted (perhaps needed by the victim), the medical-forensic investigations have to be conducted without any delay, appropriately, responsibly and, most of all, organizationally.

\section{Discussion}

\section{Activities of law enforcement agency}

Many people who have suffered a sexual abuse have, in this context, the first contact with a police officer, who is in charge of

The following responsibilities

A. Guarantee the prompt security of the victim;

B. Obtain all necessary information to complete the crime report, including the general information provided by all the witnesses, including the victim

C. Preserve the integrity of all physical evidences which might be required (e.g. footsteps, fingerprints, victim's clothes, etc.)

D. Inform the victim about the possibility of being addressed to a medical structure; if the victim decides to undergo a medical examination, organize the transport.

E. Obtain all information required to establish the crime dynamics: the typology of the crime, including a description of what happened, such as: Time and place of the aggression; the injuries on the victim; if any weapon was used; The identity or the description of the aggressor, if recognized; The presumed aggressor's job place and/or residence, if known; the escape direction of the aggressor, including the description of the vehicle, if present; Names, addresses, telephone number of any witness; Victim's address, job and telephone number. Once arrived at the medical structure, the police officer should give to the hospital personnel all information about the events [3-9].

\section{Clinical and Medico-Legal assessments}

As for the sampling of biological traces, a coordinate and attentive analysis of the various elements occurring in the places and affecting people is required, also as far as sexual abuses are concerned. The episodes of sexual violence on an adult and/or a minor are difficult to solve, as the victim, in most cases, is the only witness of the crime. The clinical analysis, the collection of physical evidences and the documentation of the injuries are sometimes the only evidence elements needed to demonstrate the validity of the facts. For example, evidences concerning the aggressor or the place where the crime was committed can be retrieved on the body or on the victim's clothes; such elements are more easily retrievable when the victim is promptly aided by doctors. On the contrary, such elements can be easily lost, as time passes between the aggression and the medical assessments.
The physical examination and the collection of evidences in contexts of sexual abuse is competence of medical doctors and specialized nurses (forensic nurses) and they can be performed already in first aid or in the genecology or podiatry wards of the health facility where the victim has been aided. Clinically speaking, the role of medical personnel is crucial in these situations, as it represents the main figure able to identify all the issues and necessities of the victim, since he or she is undoubtedly psychologically upset. The person who suffered a sexual abuse may need 3 kinds of necessities: A "physical" necessity $\rightarrow$ medical examination; an "emotional" necessity $\rightarrow$ psychological conversation; A "legal” necessity $\rightarrow$ complaint [1012].

Such kinds of necessities, once identified, have to be satisfied according to an established order and all the supportive services have to be coordinated in order to meet the exigencies of the victim.

\section{First Aid}

When the patient arrives in a first aid facility it is necessary to: Handle the crisis for the sake of the victim and his/her family; Keep the integrity of the evidences handling them the least possible, using separate bags for the conservation of clothes and of every object collected and immediately note down on a crime report all the procedures followed; Inform the patient about the importance of undergoing an immediate medical examination, of preserving the physical evidences potentially precious for a legal aim and of the possibility that the evidences might be destroyed by some activities like having shower, teeth brushing, using a mouthwash, smoking, eating and drinking.

\section{The Consent}

Obtaining a written consent for the assessments before the patient undergoes the investigations is a praxis relevant to the victims of sexual abuse, who may decide if giving or not their assent for each procedure. The informed consent is a continuous process entailing more than a simple victim's signature. Under conditions of stress, most of people might not fully understand or not remember the reasons or the meaning of all procedures and their purposes. Hence, they have to be accurately and clearly explained. In any case and in any moment of the procedure, the victim has the right of rejecting one or more exams or not answering to questions.

\section{Ideal health facility for aiding victims of abuses}

The ideal place for aiding the victims of a sexual abuse is a hospital unit, as the victim may show health problems linked to the psycho-physic trauma suffered (e.g., a head injury or intoxications), so that they may require a prompt medical treatment applying the commonest laboratory tests (clinical pathology, microbiology and toxicology). In order to host the victims of sexual violence, it is essential that the facility is equipped with a place guaranteeing privacy, both visual and auditory, that it is sufficiently illuminated, with an appropriate 
temperature of the room and equipped with a gynecological table positioned in order to let the physician examine the victim.

Besides a system for the hand washing, with tap water and soap, the place should be equipped with a forensic instrumentation (the collection of samples kit) and with the table for the reporting and the labeling of samples. It will be useful the presence of a second room equipped with shower and toilet facilities, where the specialist personnel will be able to host and to psychologically help the victim, in the meantime police officers collect information useful to the investigation. In addition, it will be useful a reception and a waiting room for victim's familiars and friends.

\section{Medical examination and immediate evaluations}

Table 1: Skin and mucous surfaces requiring an in-depth analysis.

\begin{tabular}{|c|c|}
\hline $\begin{array}{l}\text { Scalp, } \\
\text { face and } \\
\text { auricles }\end{array}$ & $\begin{array}{l}\text { The observation and the percussion of scalp may reveal } \\
\text { stiffness and swelling, characteristic of haematomas. } \\
\text { The inner part of the buccal cavity has to be carefully } \\
\text { inspected in order to exclude the presence of bruises, } \\
\text { abrasions and lacerations of the buccal mucous, which } \\
\text { may be hidden. An otoscope is used for inspecting the } \\
\text { eardrum. }\end{array}$ \\
\hline Neck & $\begin{array}{l}\text { The neck area is very interesting from a forensic point } \\
\text { of view. Digitated ecchymosis may indicate the signs of a } \\
\text { grabbing, whereas the signs of a bite have to be stopped } \\
\text { up firstly for the collection of saliva and the swab has to } \\
\text { be cited and stored, then one can medicate the area. }\end{array}$ \\
\hline $\begin{array}{l}\text { Chest and } \\
\text { abdomen }\end{array}$ & $\begin{array}{l}\text { Chest, bosoms and abdomen have to be carefully } \\
\text { examined in order to identify signs of contusions, } \\
\text { abrasions, lacerations and biological traces. The } \\
\text { thoracoabdominal percussion has to be aimed to } \\
\text { exclude the presence of possible inner traumas. }\end{array}$ \\
\hline $\begin{array}{l}\text { Upper } \\
\text { limbs }\end{array}$ & $\begin{array}{l}\text { Inner surfaces of arms and axillary glands has to be } \\
\text { carefully controlled for identifying any ecchymosis, the } \\
\text { victims immobilized by the hands of the aggressor show } \\
\text { often digitated ecchymosis on the skin surface, as well } \\
\text { as "defense injuries" can be identified on the forearms. }\end{array}$ \\
\hline $\begin{array}{l}\text { Hands, } \\
\text { wrists, } \\
\text { nails }\end{array}$ & $\begin{array}{l}\text { Hands have to be inspected also on the dorsal and } \\
\text { palmar sides, as well as the wrists have to be observed } \\
\text { also on the medial side, in order to highlight possible } \\
\text { signs of bindings. The inspection of the nails is } \\
\text { accomplished with a possible collection of the material } \\
\text { found underneath them. }\end{array}$ \\
\hline $\begin{array}{l}\text { Lower } \\
\text { limbs }\end{array}$ & $\begin{array}{l}\text { Lower limbs have to be carefully examined, in } \\
\text { particular the inner side and the area of ankles, in } \\
\text { order to highlight signs of grabbing, ecchymosis or } \\
\text { abrasions. There can be abrasions of the patellar area as } \\
\text { consequence of the aggressor obligation to drop down. }\end{array}$ \\
\hline $\begin{array}{l}\text { Perineal } \\
\text { region, } \\
\text { rectum } \\
\text { and } \\
\text { vagina }\end{array}$ & $\begin{array}{c}\text { Perineal region, rectum and vagina have to be examined } \\
\text { by specialists in order to highlight possible local } \\
\text { traumatisms which may not be noticed by an inexpert } \\
\text { eye. }\end{array}$ \\
\hline
\end{tabular}

The victims of a sexual abuse should undergo, as soon as possible, a complete and detailed medical assessment, in which physicians have to perform: an accurate and complete general medical history in order to be able to clinically intervene where necessary, in a specific, safe and in a targeted manner for the benefits of the victim; A victim-specific medical history relative to the menstrual cycle, the use of contraceptives, pregnancies, possible caesarean section, operations of pelvic surgery; A description of the events, date, time and place of the violence, The possible use of weapons or of immobilizing tools, as well as the consumption or forced administering of drugs, opiates, alcohol and their modalities; A signal to investigators about any activity carried out by the victim after the violence (e.g. shower, privates washing, use of pads, clothes changing) that might have altered the evidences; a scrupulous clinical test performed by the doctor with specific evaluation of the mental state and of vital signs (blood pressure, temperature, heart rate and ventilory frequency), as well as a top-to-toe (Table 1); At this stage, a detailed description of all skin injuries (abrasions, bruises, grazes, stab wounds, shooting iron wounds, etc.) is required, as well as a description of urogenitalis mucosa and of perineum. In order to make a more accurate description of the suffered injuries, one can use specific schemes showing the human body associated to other pictures.

During assessments, diagnostic and toxicological tests should be also performed, including:

a) Magnetic resonance imaging tests ( $\mathrm{X}$ ray, Tac, echography, resonance imaging), useful for diagnosis of fractures, cranial brain, spinal cord and thoracic-abdominal traumas;

b) Taking of a blood sample for diagnostic laboratory tests in order to determine blood alcohol levels, test $\beta$-HCG (to evaluate a possible pregnancy), microbiologic analysis to evaluate sexually transmitted infections (gonorrhoea, pox, chlamydia, trichomoniasis) and molecular analysis in order to determine viral infections such as AIDS (the HIV test requires the informed consent), papillary tumour (HPV), Herpes Simplex-2 (HSV-2), hepatitis B virus (HBV)

c) Taking of a urine sample for toxicological tests. Specifically, a research of psychotropic drug is made, capable of altering the mental activity of the patient (benzodiazepine, barbiturates, cannabinoids, hallucinogens, opiates).

\section{Samples collection and production}

The collection of the so-called forensic evidences has the objective of proving or excluding a physical link among people, objects and places. Such evidences concern a range of biological substances or objects, retrieved on the victim, on her clothes or at the place of the violence. Their analyses require specific technical-scientific competences. The close encounter among aggressor, victim and the place of the violence determines an interchange of the traces and evidences (Locard's exchange principle). Biological traces (blood, hair, semen, skin fragments) can be both found on the victim and on the aggressor; for example, victim's blood can be found on her aggressor's clothes; traces of the place (such as dirt or vegetation) can link the victim and her aggressor to a specific place. Similarly, the crime scene may provide pieces of clothes or biological material. 
On the basis of available data and of information provided by the victim and investigators, physicians, the genetic and must decide what the samples to be collected are. Dealing with such decisions, it is important to be aware about the purpose for which such samples are designed, what are the potentially essential links and if they could ease the surveys? A wide range of samples can be collected from the victim for legal purposes. Therefore, it is essential that operators understand the capabilities and the exigencies of forensic laboratories that will make the analysis, for example: Which samples can be tested? And How should they be collected, stored and carried singularly? It is important to remember that all aspects concerning the collection, the storage and the transport of forensic samples have to be realized as a chain of custody. Any failure to comply with it may affect the outcome of criminal proceedings.

When collecting the samples for a forensic use, the following principles must be respected:

i. Avoid contaminations: Make sure the samples are not contaminated from other materials; always wear gloves. Modern analysis techniques of DNA are so sophisticated they are able to notice even small traces of an extraneous DNA.

ii. Collect the samples as soon as possible: Do not let too much time pass between the events and the collection of samples, since it should be as short as possible. The probability of obtaining information may indeed diminish as time passes. The ideal situation is a collection made within $24 \mathrm{~h}$ since the moment of the violence; whenever exceeding
$72 \mathrm{~h}$, the quality and the outcomes of the collection results considerably lowered.

iii. Correctly handle the samples: Make sure the samples are packaged, stored and appropriately carried. Forensic laboratories should be able to provide indications about special requirements of handling and storage of samples: as general rule, the fluids should be refrigerated, whereas all other materials (biological traces and none) should be dried.

iv. Carefully label the samples: All samples should be labeled in order to specify: name and date of birth of the patient; name of the health professional who intervened; the typology of the sample and the date and time of the collection.

v. Guarantee the safety: Samples should be packaged with seals, in order to maintain the integrity. Generally, security coded bags are used. Moreover, the conservation of samples is just an authorized and registered personnel's prerogative.

vi. Maintaining -uity: Once the sample collected, the successive handlings have to be correctly recorded; moreover, the details about the transfer of the sample between the operators have to be noted down as well.

vii. Document the activities performed: It is a good praxis to fill out a detailed list relative to medical notes of the patient, to the reports on all collected samples and all the details about their transfers to forensic laboratories. (Table 2) shows forensic samples collected in cases of sexual abuses, together with some notes about the collecting methods.

Table 2: Forensic samples collected from victim's body and clothes.

\begin{tabular}{|c|c|c|c|c|}
\hline ZONE & $\begin{array}{l}\text { MATERIAL/ SUBSTANCE } \\
\text { TO BE ANALYSED }\end{array}$ & EMPLOYED TOOLS & $\begin{array}{l}\text { INSTRUCTIONS } \\
\text { FOR SAMPLING }\end{array}$ & NOTES \\
\hline \multirow[t]{2}{*}{$\begin{array}{l}\text { Anorectal } \\
\text { area }\end{array}$} & Semen & $\begin{array}{l}\text { Cotton swab and slides for } \\
\text { microscope analysis }\end{array}$ & $\begin{array}{l}\text { Use swabs and slides for the collection and storage of } \\
\text { materials. Dampen the tools with sterile water, not with } \\
\text { lubricants }\end{array}$ & 1 \\
\hline & Lubricant & Cotton swab & Dry the tampon after the collection & \\
\hline \multirow{2}{*}{ Blood } & Drugs & Test tube & Collect $10 \mathrm{~mL}$ of venous blood & 2 \\
\hline & Victim's DNA & Test tube & Collect $10 \mathrm{~mL}$ (or less) of blood & \\
\hline Clothes & $\begin{array}{l}\text { Extraneous material stuck } \\
\text { to clothes (blood, biological } \\
\text { fluids, hair, fibers) }\end{array}$ & Paper bags & $\begin{array}{l}\text { Clothes are to be put into paper bags. Objects or wet clothes } \\
\text { have to be dried as first, then put into separate bags }\end{array}$ & 3 \\
\hline $\begin{array}{l}\text { Vaginal, } \\
\text { perivaginal, } \\
\text { vulval area }\end{array}$ & Semen & $\begin{array}{l}\text { Cotton swab and slides for } \\
\text { microscope analysis }\end{array}$ & $\begin{array}{l}\text { Use swab and separate slides to collect biological material } \\
\text { from the vulval external area, inside the vaginal canal and in } \\
\text { cervix. Lubricate the speculum with water (not lubricant) } \\
\text { otherwise perform a blind vaginal swab }\end{array}$ & \\
\hline Hair & $\begin{array}{l}\text { Comparison with hair } \\
\text { retrieved on the crime scene }\end{array}$ & Sterile container & Collect a lock of hair and put it inside a sterile container & 4 \\
\hline \multirow{2}{*}{$\begin{array}{l}\text { Oral and } \\
\text { perioral } \\
\text { area }\end{array}$} & Semen & $\begin{array}{l}\text { Cotton swabs, sterile } \\
\text { container (for oral washes) } \\
\text { or dental floss }\end{array}$ & $\begin{array}{l}\text { To Tampon the different mouth areas with one or more } \\
\text { swabs. In order to obtain a sample through mouth washing, } \\
\text { rinse the mouth with } 10 \mathrm{~mL} \text { of water and collect into a } \\
\text { container }\end{array}$ & \\
\hline & $\begin{array}{l}\text { Saliva (containing nucleate } \\
\text { cells for the analysis of } \\
\text { victim's DNA) }\end{array}$ & Cotton swab & & 5 \\
\hline
\end{tabular}


Journal of Forensic Sciences \& Criminal Investigation

\begin{tabular}{|c|c|c|c|c|}
\hline Nails & $\begin{array}{c}\text { Skin fragments, blood, fibres } \\
\text { (belonging to the aggressor) }\end{array}$ & $\begin{array}{c}\text { Sterile toothpicks or } \\
\text { specific cotton swab }\end{array}$ & $\begin{array}{c}\text { Use sterile toothpicks to collect biological material under the } \\
\text { victim's nails, cut them and put them into sterile containers. } \\
\text { Use also cotton swabs conceived for such purpose }\end{array}$ & $\begin{array}{c}\text { Pads have to collected if used by the victim before or after } \\
\text { the violence }\end{array}$ \\
\hline Pads & $\begin{array}{c}\text { Extraneous material } \\
\text { (semen, blood, hair) }\end{array}$ & Sterile containers & Tampon the areas where it could occur \\
\hline \multirow{3}{*}{ Skin } & $\begin{array}{c}\text { Semen } \\
\text { Blood, saliva, (in areas } \\
\text { where possible kisses, bites } \\
\text { or liking were inflicted by } \\
\text { the aggressor) }\end{array}$ & Cotton swab & Dry the swabs after collection \\
\cline { 2 - 5 } & $\begin{array}{c}\text { Extraneous material } \\
\text { (vegetation, extraneous } \\
\text { hair) }\end{array}$ & Swabs, tweezers & Put the material inside sterile containers (bags or bottles) & 1 \\
\hline Urine & Drugs & Sterile container & Collect 100 mL of urine \\
\hline
\end{tabular}

\section{Notes}

a) The following general procedures apply to the use of swabs for the collection of materials subject to forensic analysis: Perform at least two sterile cotton or nylon swabs (or swabs recommended by the laboratory); After the collection, do not store the sample in test tubes containing gel or terrain (in order to avoid the bacterial proliferation and the destruction of biological material). Only samples intended for microbiological analysis can be put into a fluid or a liquid; Dampen the samples with sterile water or salt solution during the collection of materials of dry surfaces (e.g. skin, anal area); In order to examine the collected sample through a microscope (e.g. for testing the presence of sperms), the slides should be prepared. Label them and, after the collection of the swab, make the swab point rotate on the slide. Both the swab and the slides should be sent to the laboratory for forensic examination (see genetic forensic assessments). All the swabs and slides should be carefully dried before sealing in the designed containers for transfer.

b) Toxicological analyses are suggested in case the victim is likely to have been sedated or stunned before the violence. If the victim is helped in the hospital within 12$14 \mathrm{~h}$ since the possible administration of psychotropic drugs, a sample of venous blood can be taken in order to perform the toxicological tests. Whenever the time span between the violence and the medical first aid is longer, a sample of urines should be taken, since the possible drugs or opiates administrated are no more retrievable in the blood, but have been metabolized and eliminated through urinary passage.

c) There are many ways to collect extraneous material retrieved on the victim's skin and/or clothes. If such material stuck on the victim's skin and/or clothes, it can be asked to the victim to get undressed on a big sheet of paper, so that each kind of material falls down on it and will be able to be taken with sterile tweezers; otherwise, the whole sheet has to be folded up and sent to the laboratory. Alternatively, the victim's clothes are collected and sent to the laboratory.
Should they be wet, they have to be dried before being sent to the laboratory.

d) The collection of hair retrieved on the scalp is seldom suggested, but it can be useful in case hairs are retrieved on the crime scene. A lock of hair sample is considered adequate. Pubic hair can be "combed" in order to find aggressor's pubic hair. The comb is then transferred to the laboratory in a sterile container.

e) The curettage through a cotton swab in the inner part of the cheek (i.e. a buccal swab) will collect enough cell material for the analysis of the genotypic profile of the victim; alternatively, a small quantity of victim's blood can be taken Oral swabs should be carefully dried after the collection. Such kind of oral swab should not be performed when there could be the possibility of the presence of extraneous biological material in victim's mouth (e.g. ejaculation of the aggressor into victim's mouth).

f) In case the victim scratched her aggressor during the violence, aggressor's biologic material can be retrieved under victim's nails through toothpicks or nylon samples conceived for the DNA analysis.

g) Victim's pads should be well dried in the air, and, if possible, wrapped into a tissue and stored inside a paper bag.

\section{Genetic Forensic assessments}

Once the evidences collected (from victim's body, clothes and from the crime scene) and transferred to a forensic genetic laboratory, they will undergo a series of tests with the aim of researching biological traces, of defining their origins (blood, semen, saliva or other fluids) and the specie (human or animal) This preliminary phase concluded, one can proceed with the molecular exams on samples, including: DNA extraction from nucleated cells fund in the examined biological traces; Quality and quantitative analysis of DNA in order to establish the quantity of nuclear DNA, the possible presence of male DNA 
(in cases of sexual abuse it is crucial to know this value), the presence of substances that may inhibit the molecular reactions, and the level of degradation of DNA; Typing of STR polymorphic markers, i.e. DNA regions highly variable able to distinguish an individual from one another; Obtaining of genetic profiles of examined traces and comparisons with reference genetic profiles (victim and possible suspects); Biostatic an calculations in order to establish the "weight" of this source of evidence for legal purposes [13-15].

It is essential, in this context, to examine in depth some aspects dealing with the analysis of the origins of biological traces, in particular for the purpose of confirming the presence of semen and of possible spermatozoa's. Such elements are determined in cases of sexual abuses.

\section{Differential DNA extraction}

The different analytic processes of biological samples designed to the extraction of genetic profiles have been diffusely afforded in other reviews, and we will not deal with them. It is important, however, to highlight that forensic samples derived from sexual abuse are characterized by the coexistence of epithelial female cells and spermatic cells. The letters are characterized by a major resistance to the classic procedures of DNA extraction; therefore, forensic geneticians take advantage of this physic characteristic of spermatozoa's for the purpose of separating the epithelial cells of the victim from the spermatic cells of the aggressor, in order to ease the interpretation of the aggressor's genetic profile. The main techniques of differential extraction are the following: Differential cell lysis. Such method represents the gold standard of the techniques used for this procedure. It preferentially entails the separation of epithelial female cells after incubation with detergents and proteinases. Once the DNA isolated and collected, together with feminine cell debris, spermatozoas are lysed undergoing the action of detergents, proteinases and thiols; the letters break the structure of the nuclear spermatic membrane. In this way, aggressor's DNA is separately retrieved from victim's DNA, then is processed and analysed by forensic geneticians. Approach with DNAse. Such technique requires the victim's DNA digestion thanks to the action of DNA ases, i.e. proteolytic enzymes capable of degrading the DNA. In this case, only aggressor's DNA remains intact in order to be analysed. Laser Capture Microdissection (LCM). Spermatic cells can be selectively captured using this clinical procedure, commonly employed in the medical field in order to highlight and isolate tumorous cells from the healthy tissue, via microscopic visualization. When spermatic cells are observed through microscope, a minuscule laser is activated, conceived to melt a thin plastic film put above the slide on a specific point of it, and capturing the interested cells. Moving the slide, dozens spermatic cells will be collected on this thin film and put into test tubes for the DNA extraction phase and for the following molecular analysis [16].

\section{Conclusion}

Medical, psychological and legal procedures performed on the victim of a sexual abuse are many, complex and delicate. They require privacy, respect, full availability and expertise, as all people involved are concerned (police officers, physicians, legal doctors, forensic geneticists and psychological support personnel), as well as adequate places and equipment in order to face each kind of exigency and emergence.

Moreover, during the laboratory analysis of samples collected by the victim and/or from her clothes, it is important to verify the presence of semen through test approved by the international forensic community and, if possible, to make also the direct visualization of spermatozoa's by means of optical microscope. The analysis made through microscope has a high probative level in cases of rape and sexual abuse, as it is an unquestionable sign of the presence of a male sex subject. The success of a survey aimed to prove the existence of a crime and to identify the aggressor depends on a coordinated and accurate combined action of professionals and analytical techniques; the emerging of working groups that use standardized shared protocols is the route to follow, if actually wanting to help the Administration of Justice and to identify criminals.

\section{Acknowledgement}

I want to thank Dr. Emiliano Giardina, university professor of medical genetics and director of forensic genetics laboratory at the University of Rome "Tor Vergata" (Italy), with whom I have obtained a master's course in forensic genetics, and I have collaborated on several criminal cases. His teachings allowed me to fully understand the forensic genetics, to provide support to justice and to all citizens who need our help. For this reason I have written this article along with Dr. Giardina, to say to the women and to all victims of violence that they are not alone, but we are there!!

\section{References}

1. World Health Organization (2003) Guidelines for medico-legal care of victims of sexual violence. pp. 1-154.

2. World Health Organization (2005) Multi-country Study on Women's Health and Domestic Violence.

3. World Health Organization (2002) World report on violence and health.

4. World Health Organization (2013) Responding to intimate partner violence and sexual violence against women WHO clinical and policy guidelines.

5. Italian Forensic Geneticists (Ge.F.I) Guidelines for the evidence collection of biological traces to the analysis of forensic genetics in the care pathway of the victims of sexual assault and / or mistreatment.

6. A National Protocol for Sexual Assault Medical Forensic Examinations (adult/adolescent). ( $2^{\text {nd }}$ edn), U.S. Department of Justice, Office on Violence against Women, NCJ 228119 pp. 1-144.

7. Z Jakovski, R Jankova, A Duma, B Janeska, G Pavlovski, et al. (2013) Forensic approach to analyzing rape cases. Forensic Science International: Genetics Supplement Series 4: e45-e46. 
8. Butler JM (2010) Fundamentals of Forensic DNA Typing ( $1^{\text {st }}$ edn) Elsevier Academic Press, San Diego.

9. Butler JM (2012) Advanced Topics in Forensic DNA Typing: Methodology ( $1^{\text {st }}$ edn $)$. Elsevier Academic Press, San Diego.

10. Forensic Light Source Applications: Wavelengths and Uses, Horiba.

11. Baechtel FS (1988) The identification and individualization of semen stains. In: Saferstein R, ed. The Forensic Science Handbook, Vol. 2. Englewood Cliffs, Prentice Hall, New Jersey.

12. Independent Forensic DNA testing and Technologies, RSID Semen.

13. Leubitz S, Savage RA (1984) Sensitivity of Picroindigocarmine/ Nuclear Fast Red (PIC/NF) Stain for the Detection of Spermatozoa: A
Serial Dilution Study of Human Ejaculate. American Journal of Clinical Pathology 81: 90-93.

14. John Herr (2007) Sperm Paint Optimization and Validation. 2000-IJCX-K013.

15. Greenspoon SA, Ban JD, Sykes K, Ballard EJ, Edler SS, et al. (2004) Application of the BioMek 2000 Laboratory Automation Workstation and the DNA IQ System to the extraction of forensic casework samples. J. Forensic Sci 49: 29-39.

16.Vandewoestyne M, Deforce D (2010) Laser capture microdissection in forensic research: a review. Int J Legal Med 124(6): 513-521.
This work is licensed under Creative Commons Attribution 4.0 License

DOI: $10.19080 /$ JFSCI.2017.03.555627 